\title{
Enhancing the performance of xanthan gum in water-based mud systems using an environmentally friendly biopolymer
}

\author{
Emmanuel U. Akpan ${ }^{1}$ (D. Godpower C. Enyi ${ }^{1} \cdot$ Ghasem G. Nasr $^{1}$
}

Received: 1 August 2019 / Accepted: 9 January 2020 / Published online: 3 February 2020

(c) The Author(s) 2020

\begin{abstract}
Xanthan gum is commonly used in drilling fluids to provide viscosity, solid suspension, and fluid-loss control. However, it is sensitive to high temperatures and not tolerant of field contaminants. This paper presents an experimental study on the effects of an eco-friendly biopolymer (diutan gum) on xanthan gum (XC) in a water-based bentonite mud. Laboratory experiments were carried out for different compositions of the biopolymers in water-based bentonite muds formulated without salt and in water-based bentonite muds containing sodium chloride $(\mathrm{NaCl})$. The rheological properties of the water-based bentonite muds formulated with XC (2 Ibm) and those of the water-based bentonite muds prepared using XC (1Ibm) and diutan gum (1Ibm) were measured using Model 1100 viscometer after aging at $25^{\circ} \mathrm{C}, 100{ }^{\circ} \mathrm{C}$, and $120^{\circ} \mathrm{C}$ for $16 \mathrm{~h}$. The API fluid loss and filter cake of the mud formulations were measured using HTHP filter press. The properties of the water-based bentonite muds containing only XC were compared with those of the water-based bentonite muds containing XC and diutan gum. Presented results show that combining diutan gum and xanthan gum in a ratio of 1:1 in a water-based bentonite mud enhances its performance with respect to fluid properties—apparent viscosity, gel strength, yield points, YP/PV ratio, LSRV, $n$, and $K$. The fluid formulations also showed favorable mud cake building characteristics. Experimental data also indicate a $16 \%, 19 \%$, and $34 \%$ reduction in API fluid loss values for the water-based benitoite muds containing XC in the presence of diutan gum after aging at $25^{\circ} \mathrm{C}, 100{ }^{\circ} \mathrm{C}$, and $120^{\circ} \mathrm{C}$ for $16 \mathrm{~h}$, respectively. Experimental results also show that the waterbased benitoite mud containing XC and diutan gum would cause less formation damage and was tolerant of contamination with a monovalent cation $\left(\mathrm{Na}^{+}\right)$. The synergy of xanthan gum and diutan gum can, therefore, improve the performance of water-based drilling fluids.
\end{abstract}

Keywords Viscosity $\cdot$ Fluid loss $\cdot$ Stability temperature $\cdot$ Drilling fluid $\cdot$ Oil-based mud

$\begin{array}{ll}\text { Abbreviations } \\ \text { API } & \text { American Petroleum Institute } \\ \text { AHR } & \text { After hot rolling } \\ \text { ASH } & \text { After static aging } \\ \text { Bent. } & \text { Bentonite } \\ \text { DG } & \text { Diutan gum } \\ \text { G } & \text { Grams } \\ \text { h } & \text { Hour }\end{array}$

Emmanuel U. Akpan

e.u.akpan@edu.salford.ac.uk

Godpower C. Enyi

g.c.enyi@salford.ac.uk

Ghasem G. Nasr

g.g.nasr@salford.ac.uk

1 Petroleum Technology and Spray Research Group, School of Computing Science and Engineering, University of Salford, Manchester M5 4WT, UK

$\begin{array}{ll}\text { HTHP } & \text { High Temperature High Pressure } \\ \text { Ibm } & \text { Pound mass } \\ K & \text { Fluid consistency index } \\ \text { LSRV } & \text { Low shear rate viscosity } \\ \text { ml } & \text { Milliliter } \\ \text { min } & \text { Minute } \\ n & \text { Flow behavior index } \\ \text { PV } & \text { Plastic viscosity } \\ \text { s }^{-1} & \text { Per second } \\ \text { XC } & \text { Xanthan gum } \\ \text { YP } & \text { Yield point }\end{array}$

\section{Introduction}

Polymers are used in almost all water-based muds, and any drilling mud systems that are made up of soluble polymers can be referred to as polymer muds. The function 
of polymers in drilling muds is to provide viscosity, shale inhibition and fluid-loss control, and to prevent clay dispersion (Galindo et al. 2015). Polymers are classified into natural, synthetic, and modified natural polymers. Synthetic polymers are stable at high temperatures (Strickland 1994; Plank 1992) but generate high plastic viscosity (Tehrani et al. 2007). Conversely, biopolymers are non-toxic and less expensive and have less effect on formation damage (Mahto et al. 2004, 2005). In addition, biopolymers are environmentally friendly (Dayawant 1999), enhance the properties of water-based muds even at low concentrations (Darley and Gray 1988), and can be used separately or mixed together to improve bentonite performance (Darley and Gray 1988). Nevertheless, drilling fluids containing biopolymers have some limitations: High solid contents (Amoco Production Company 1994) and high temperatures are a major challenge to running biopolymer-based muds successfully (Tehrani et al. 2007; Galindo et al. 2015; Bradshaw et al. 2006; Zheng et al. 2019). High temperatures cause the degradation of biopolymers in drilling muds (Wenjun et al. 2014; Tehrani et al. 2009; Zhang 2016), thus leading to the decrease or total loss in viscosity and other properties of drilling fluids (Weaver et al. 2003). Ezell et al. (2010) evaluated a water-based drilling fluid formulation designed to perform efficiently during drilling operation. The additives used in the mud formulation include starches, derivatized starches, gums, derivatized gums, and cellulosic. According to Ezell et al. (2010), cross-linked starches degrade when subjected to temperatures above $300{ }^{\circ} \mathrm{F}$. They concluded that biopolymers cannot be successfully deployed at temperatures exceeding $300{ }^{\circ} \mathrm{F}$. Consequently, biopolymer-based muds are deployed in environments with temperatures lower than $300{ }^{\circ} \mathrm{F}\left(150{ }^{\circ} \mathrm{C}\right)$ (Galindo et al. 2015). For example, xanthan gum is a commonly used biopolymer in completion and drilling fluids. For a long time, it has been found to be efficient in providing viscosity and fluid loss control in water-based mud systems and in completion fluids (Howard 1995). It is also effective in minimizing reservoir formation damage (Powell et al. 1995). However, xanthan has limitations with respect to its sensitivity to temperature and to its tolerance to contaminants (Gallino and Xiao 1996). Sarber et al. (2010) compared the performance of drilling fluid formulated with diutan gum and with that of the mud formulated with xanthan gum. They found out that the diutan-based solid-free mud performs better than xanthan gumbased solid-free mud. However, the mud formulations were sensitive to increasing temperatures. In addition, the viscosity of xanthan gum in drilling fluids with low salt concentrations collapses rapidly at $70-120^{\circ} \mathrm{C}$; this sharp collapse in viscosity can be a problem where viscosity maintenance is required (Howard et al. 2015).

Viscosity is an important property of drilling fluids. If the viscosity of drilling mud is negligible, solids descend to the bottom of a well-bore. High viscosity is essential for efficient hole cleaning (Powell et al. 1991; Zamora et al. 1993). Another property of drilling mud is gel strength, which is the capacity of drilling mud to suspend cuttings and weighting materials when fluid circulation is stopped (Mitchel and Miska 2011). If a drilling mud has no gel strength, solids will settle to the bottom of a well-bore even though it has a high viscosity. The rate of solids settling in a drilling mud can only be slowed down by a high viscosity. Furthermore, drilling fluids with low gel strengths cannot suspend solids efficiently. Yield point (YP), plastic viscosity (PV), low shear viscosity (LSRV), flow behavior index $(n)$, and fluid consistency index $(K)$ are also properties of drilling fluid. The YP/PV ratio shows the velocity profile of a drilling fluid as it flows through the space between a drill pipe and drilled hole wall, called the annulus. For a mud to transport cuttings efficiently, a flat velocity profile is required; a high YP/PV ratio gives a flatter profile (Samaei and Tahmasbi 2007). In addition, a high (YP/PV) ratio or low $\mathrm{n}$ value provides better cuttings transport and hole cleaning (Okrajni and Azar 1986). The two functions of a drilling mud associated with yield points are (1) to clean a drilled hole and (2) to control pressure. Improper hole cleaning or drilled-cutting transportation impacts drilling operations. If the well-bore is not clean efficiently, drilling problems such as low rate of penetration (ROP), bit wear, and stuck pipe may arise (Al-Azani et al. 2019). A high yield point enhances the solids carrying characteristics of a drilling fluid and increases the pressure drop in the well-bore (Annis and Smith 1996); it must be high enough to enable the carrying of drilled cuttings and weighting materials out of a well-bore, but not be too high to create excessive pump pressure when the pump starts to pump mud. A high yield point implies that a drilling mud is non-Newtonian and can carry cutting better than any mud with a lower yield point. In addition, the filtration control and mud cake building properties of drilling muds are very essential in oil well drilling. For successful completion of a well, a drilling mud must be able to deposit a thin, lowpermeability mud cake to prevent the flow of mud filtrate into the formation. An efficient drilling mud must allow an insignificant volume of mud filtrate into a formation (Adebayo and Bageri 2019). The mud cake formed on the wellbore must be thin as thick mud cake could cause differential pressure pipe sticking, difficulty in running casing, logging difficulties, torque, drag, and poor cement job.

Many researchers have undertaken research work to investigate how the combination of different polymers in a drilling fluid improves its properties. Ujma et al. (1989) showed that synergy of sulfonated polymer and starch resulted in a $50^{\circ} \mathrm{F}\left(25^{\circ} \mathrm{C}\right)$ increase in stability temperature of starch, improved drilling mud performance, and reduced costs in the German Zechstein formation. Drilling muds formulated with polyanionic cellulose (PAC) and carboxymethylcellulose 
(CMC) were problematic in the formation. However, they reported that the combination of the sulfonated polymer with $\mathrm{CMC}$ and PAC enhanced the performance of drilling fluids in the formation. Gallino et al. (1997) investigated the performance of innovative polymer mud formulations that Agip S.P.A used to drill plastic shale in south Italy. The muds were formulated with K-acetate and K-formate polymers. The result showed an increase in ROP and a reduction in bit balling or reaming time as well as in the volume of wastes generated per hole volume. However, the presence of potassium salts caused an increase in mixing costs per hole volume. Kjøsnes et al. (2003) developed a water-based drilling mud with polyanionic cellulose and xanthan gum. They reported that the mud formulation improved hole cleaning and stability. Sharma and Mahto (2006) formulated drilling fluids using biopolymers, tamarind gum, and tragacanth gum. The result showed that using the two biopolymers in a drilling fluid improved its rheological properties with less formation damage. Sharma and Mahto (2006) investigated the effects of tamarind gum and polyanionic cellulose on water-based bentonite muds. The experiment results showed that the mud formulations had favorable rheological properties and fluid loss characteristics. The mud filtrate exhibited minimum formation damage on sandstone cores. More than two polymers can also be used to formulate polymer-based muds. For example, Abdon et al. (1989) developed a high solid deflocculated polymer (HSDP) drilling fluid using three polymers. The mud formulation showed tolerance to contamination with cations $\left(\mathrm{Na}^{+}, \mathrm{Mg}^{++}, \mathrm{Ca}^{++}\right)$, carbonates $\left(\mathrm{CO}_{3}{ }^{-}, \mathrm{HCO}_{3}{ }^{-}\right)$, oil, gases, and water; and to the presence of drilled solids. Young and Ramses (2006) formulated a water-based mud using six polymers. They reported that the formulated mud performed like an invert emulsion-mud.

All these efforts of researcher have brought to the fore the attempt made in using more than one biopolymer to stabilize water-based drilling fluids. None has, however, considered the combination of biopolymers used in this work. The objective of this study was to investigate the effects of an eco-friendly biopolymer (diutan gum) on xanthan gum in a water-based bentonite mud formulated without salt and in water-based bentonite muds containing salt $(\mathrm{NaCl})$ as a fluid contaminant. The goal of this work was to measure the rheological properties and API fluid loss of drilling mud formulations through laboratory experiments and thereby determine the drilling muds that have favorable properties.

\section{Experimental}

\section{Materials}

The mud additives used in this study were freshwater, bentonite, diutan gum, xanthan gum, and sodium chloride $(\mathrm{NaCl})$. The freshwater served as the base fluid and as a means for conditioning the bentonite and other additives used in the drilling fluid preparations. The sodium bentonite provided the initial viscosity, suspension, and fluid loss control. The concentration of the bentonite was kept low as high solid contents in drilling muds could cause problems such as pipe sticking (Darley and Gray 1988). The quantity of bentonite used was $10.5 \mathrm{lbm}(3 \% \mathrm{w} / \mathrm{v}$ concentration). 2-3\% bentonite concentration is used in polymer mud systems in oil fields (Dayawant 1999; Sharma et al. 2003). The function of the biopolymers, diutan gum, and xanthan gum was to provide viscosity and fluid-loss control. Sodium chloride $(\mathrm{NaCl})$ was used as a fluid contaminant. Bentonite was bought from Hilton Instrument, Aberdeen; CP Kelco, USA, provided diutan gum and xanthan gum; sodium chloride $(\mathrm{NaCl})$ was bought from Fisher Scientific, UK.

\section{Diutan gum}

Diutan gum, a bio-fermented polymer, is produced by a bacterial strain of the Sphingomonas genus. It has a high molecular weight. At low concentration, it generates high viscosity (Navarrete et al. 2001). It is an anionic polymer. Its molecular weight is about 2.88-5.18 million Daltons (Sakata et al. 2003). Figure 1 shows the chemical structure of diutan gum (Navarrete et al. 2001).

\section{Xanthan gum}

Xanthan gum, a polysaccharide is made using microbial fermentation with the Xanthomonas campestris bacterium.
Fig. 1 Chemical structure of diutan gum
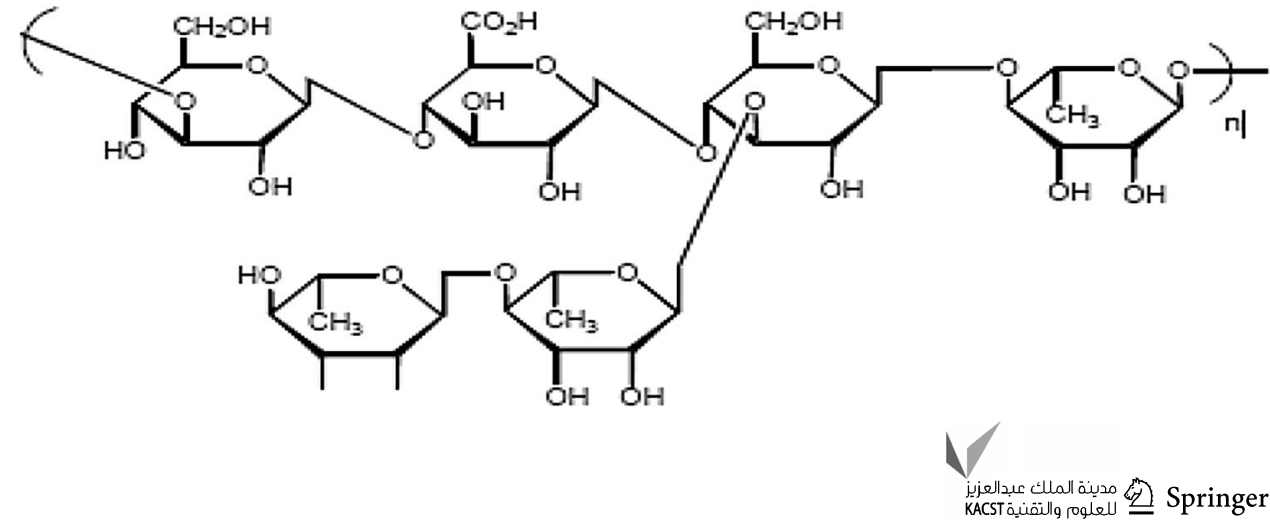
Its structure is based on cellulose backbone having alternate glucosyl residues substituted by a trisaccharide chain of D-mannose, D-glucuronic acid, and a terminal D-mannose. It has high viscosity at low concentrations (Kumara et al. 2012). It is utilized in the petroleum industries because of its properties (Sutherland 1996). Xanthan gum has an average molecular weight of $3 \times 10^{5}-7.5 \times 10^{6} \mathrm{~g} \mathrm{~mol}^{-1}$ or greater. Consequently, its molecules can aggregate (Cano-Barrita and Leon-Matinez 2016). Figure 2 shows the chemical structure of xanthan gum (Sancet et al. 2018).

\section{Experimental apparatus and procedure}

The Hamilton beach mixer [Fig. 3a (Akpan et al. 2019)] was used in this study for drilling fluid mixing. The drilling mud additives were added to $350 \mathrm{ml}$ (one lab barrel) of tap water in a mud cup. Thereafter, the mud cup was placed under the spindle of the Hamilton beach mixer, and its contents were stirred at room temperature for $30 \mathrm{~min}$. The 3 -speed switch was used to regulate the stirring speed.

The Model 1100 viscometer, which is fully automated, was used to measure the shear stress, shear rate, apparent viscosity, low shear viscosity (LSRV), $n$ (flow behavior index), $K$ (fluid consistency index), yield point (YP), plastic viscosity (PV), and gel strength of the formulated drilling muds at $25^{\circ} \mathrm{C}$. The $\mathrm{YP} / \mathrm{PV}$ ratios were calculated from the measured $\mathrm{YP}_{\mathrm{s}}$ and $\mathrm{PV}_{\mathrm{s}}$.

The Model 1100 pressurized viscometer, operated with ORCADA $^{\circledR}$ software portable, has a speed (RPM) accuracy of 0.001 (OFI Testing Equipment Inc, 2015). In this study, this device was calibrated before testing. The test results were displayed on an Excel Spreadsheet. With respect to the ORCADA ${ }^{\circledR}$ software, analysis models are based on the following: The power law model ( $n$ and $K$ ); the Bingham plastic analysis model [(PV) and (YP)]; and the power law and Bingham plastic models combined. In this investigation, the combination of the Herschel-Bulkley model, the power law and Bingham plastic models was chosen. Figure $3 \mathrm{~b}$ shows the Model 1100 pressurized viscometer and laptop computer (Akpan et al. 2019). The Herschel-Bulkley is a three-parameter model (Mitchel and Miska 2011):
$\tau=\tau_{y}+K \gamma^{n}$

where the fluid consistency index is $K$; the flow behavior index is $n$.

The Herschel-Bulkley model can represent a yield-pseudoplastic fluid $(n<1)$, a dilatant fluid $(n>1)$, a pseudoplastic fluid $\left(\tau_{y}=0, n<1\right)$, a plastic fluid $(n=1)$, or a Newtonian fluid $\left(\tau_{y}=0, n=1\right)$ (Mitchel and Miska 2011). It gives the best fit of the viscometer measurements when compared with the other rheological models (Melo et al. 1995). The power law model defines a fluid by two parameters (Mitchel and Miska 2011):

$\tau=K \gamma^{n}$

where the fluid consistency index is $K$, and the flow behavior index is $n . K$ is the viscosity at shear rate of $1 \mathrm{~s}^{-1}$ and is expressed in $\mathrm{Ib} / 100 \mathrm{ft}^{2}$. It is a measure of mud's thickness and an important drilling fluid parameter. It decreases with increasing temperature (Demirdal et al. 2007), and it is considered when designing the transport requirements of a drilling fluid. The flow behavior index, n, shows the extent of shear thinning. The smaller the value of $n$, the higher the shear thinning behavior. Its equation is suitable for modeling water-based polymer muds, most especially the polymer mud containing $\mathrm{XC}$, and is better than that of any other two-parameter model, including Bingham plastic model (Chilingarian and Vorabutr 1981). It is effective under low-shear-rate condition but ineffective at high shear rates (Hemphill et al. 1993). The Bingham plastic model also defines a fluid by two parameters as:

$\tau=Y P+P V \gamma$

$\tau$ is the shear stress; $\gamma$ is the shear rate; YP is the yield point; and $\mathrm{PV}$ is the plastic viscosity.

When shear stresses are above the yield point, the viscosity of a Bingham plastic fluid is equal to the plastic viscosity (Mitchel and Miska 2011). The sources of error in measurements from the Model 1100 pressurized viscometer are as follows (OFI Testing Equipment Inc. 2015):

- The software not calibrated before use.
Fig. 2 Chemical structure of xanthan gum

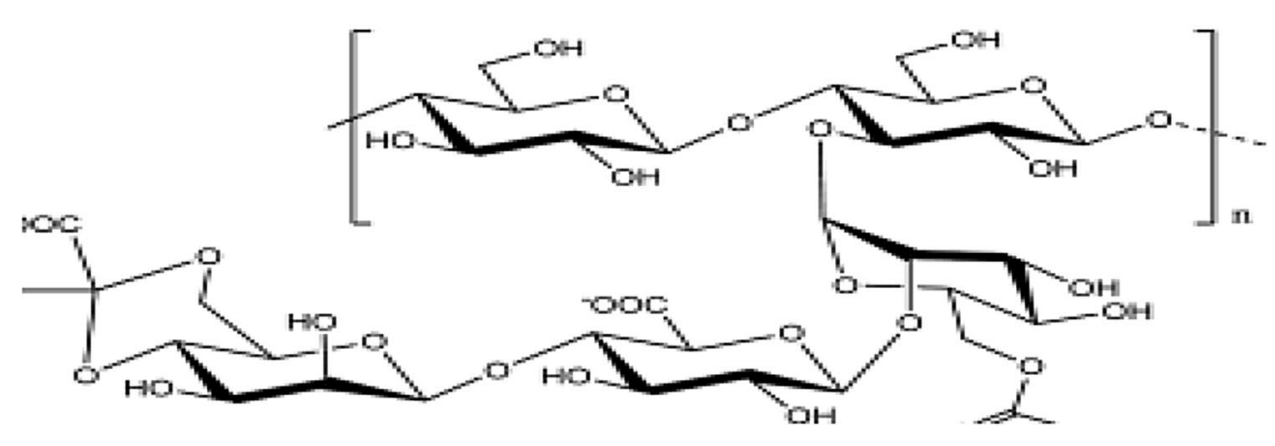




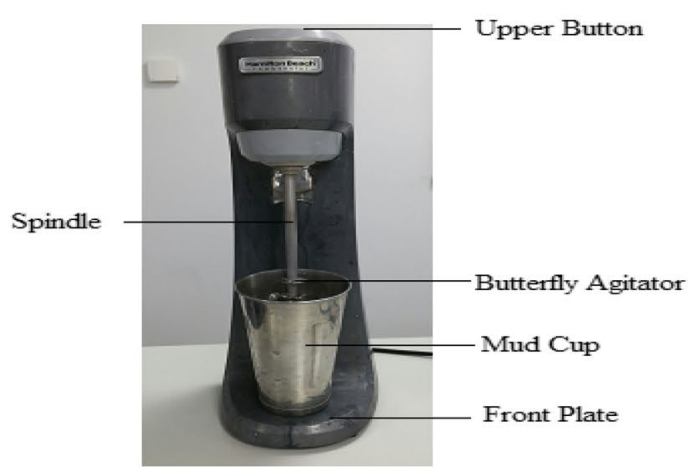

(a)

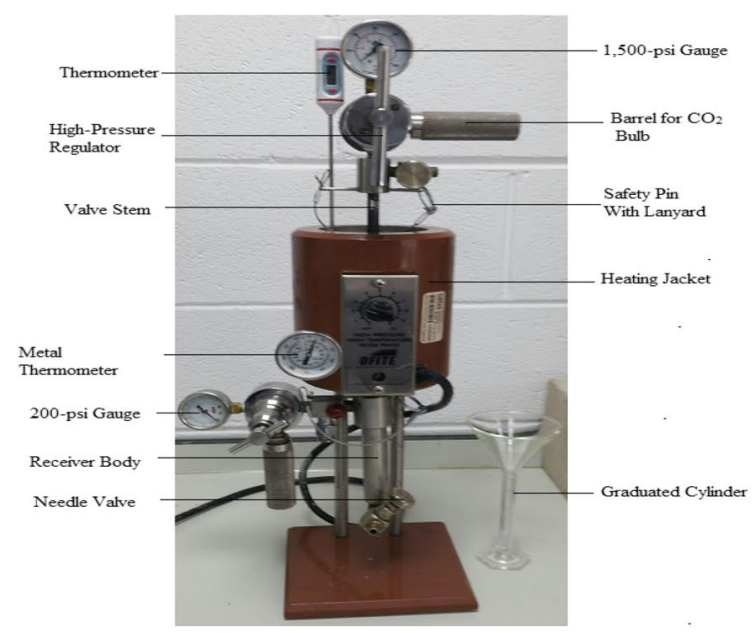

(c)

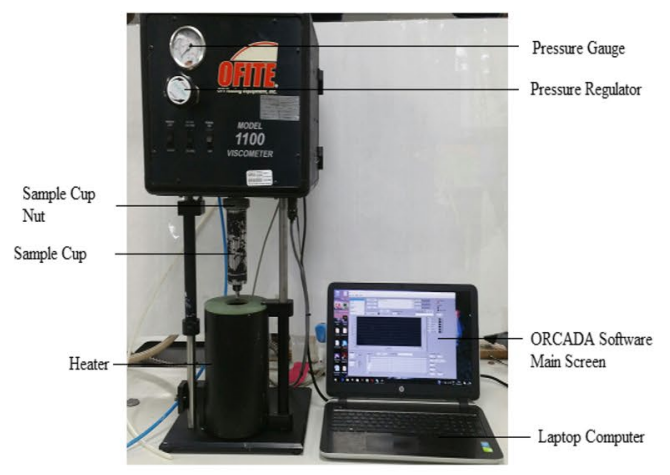

(b)

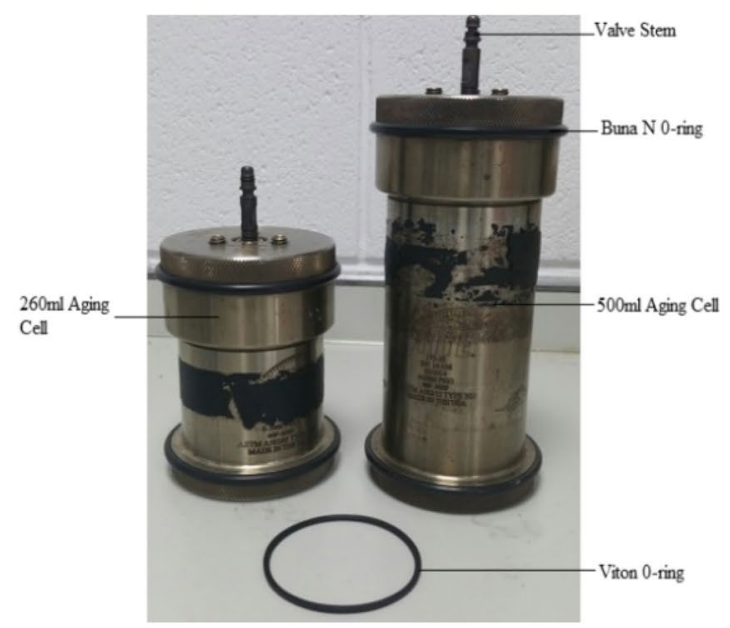

(d)

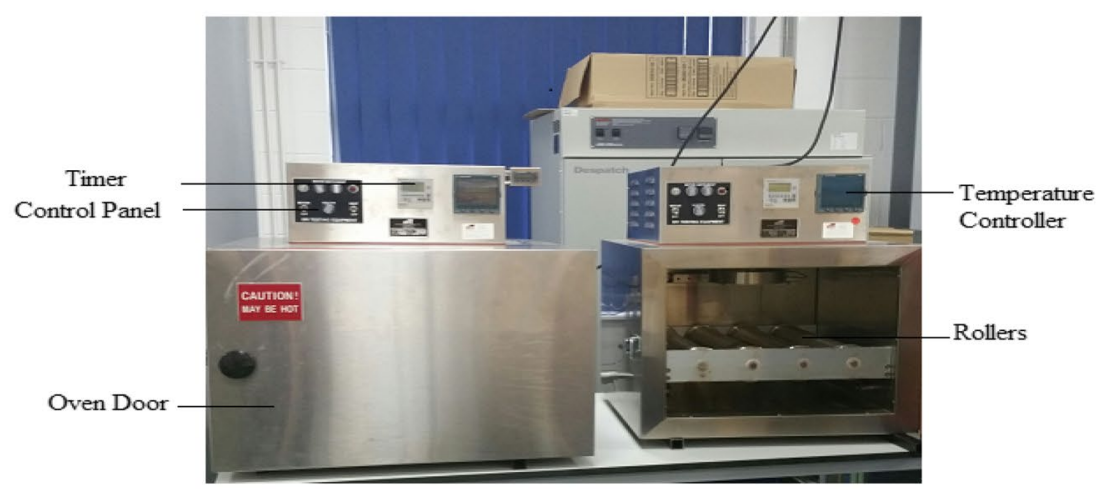

(e)

Fig. 3 Experimental apparatuses: a Hamilton beach mixer; b Model 1100 viscometer and a laptop computer; c HTHP filter press; d aging cells; e roller oven

- Test not carried at a specified temperature.

- Test carried out with "Shear Stress Raw" value drifting more than 2 or 3 units.

- Calibrating the software at speeds above 300RPM.
- Using contaminated and expired calibration fluids.

HTHP filter press (Fig. 3c) (static filtration) was used to determine the filter cake thickness and API fluid loss of the 
fluid formulations at room temperature and a pressure of 100 psi for $30 \mathrm{~min}$. The drilling mud was filtered with a filter paper. The volume of filtrate collected in $30 \mathrm{~min}$ was measured, and the thickness of the mud cake was measured to the nearest 1/32in $(0.8 \mathrm{~mm})$.

Darcy's law describes the flow of drilling fluid filtrate through a filter cake. The filtration rate is given by:

$\frac{\mathrm{d} V}{\mathrm{~d} t}=\frac{K A \Delta P}{\mu h}$

where

$\mathrm{d} V / \mathrm{d} t$ is the mud filtrate rate $\left(\mathrm{cm}^{3} / \mathrm{s}\right)$.

$K$ is the permeability of the filter cake (darcies).

$A$ is the area of the filter paper $\left(\mathrm{cm}^{2}\right)$.

$\mu$ is the viscosity of the mud filtrate (cP).

$h$ is the thickness of the filter cake $(\mathrm{cm})$.

The solids volume in the drilling fluid filtered is equal to the solids volume deposited in the filter cake at any time $t$ :

$f_{\mathrm{m}} V_{\mathrm{m}}=f_{\mathrm{c}} h A$

$f_{\mathrm{m}}(h A+V)=f_{\mathrm{c}} h A$

$f_{\mathrm{m}}$ is the volume fraction of solids in a mud

$f_{\mathrm{c}}$ is the volume fraction in a mud cake.

Therefore,

$h=\frac{f_{\mathrm{m}} V}{A\left(f_{\mathrm{c}}-f_{\mathrm{m}}\right)}=\frac{V}{A\left(\frac{f_{\mathrm{c}}}{f_{\mathrm{m}}}-1\right)}$

By substituting Eq. (5) in Eq. (4) and integrating, the filtrate volume can be given by:

$V=\sqrt{2 k \Delta P\left(\frac{f_{\mathrm{c}}}{f_{\mathrm{m}}}-1\right)} A \frac{\sqrt{t}}{\sqrt{\mu}}$ where $V=$ the filtrate volume. Equation (8) shows that the volume of the filtrate is propositional to the square root of the period of the test and inversely proportional to the square root of the viscosity of the filtrate. Therefore, the volume of the filtrate will increase with temperature since the viscosity of a liquid decreases with increasing temperature. The term $2 k \Delta P$ will remain constant: Pressure does not have much effect on filtration as the mud cake permeability decreases with an increase in pressure (Mitchel and Miska 2011).

The drilling muds were poured into aging cells and pressurized at the temperature of the boiling point of water and above to maintain the fluids in a liquid state. Figure $3 \mathrm{~d}$ shows the aging cells (Akpan et al. 2019). The aging cells were used for both static and dynamic aging of the mud formulations. The sources of error in measurements when using the aging cells are follows:

- Defective O-ring

- Overfilling the cell

- Drilling mud not pressurized with a specified pressure

- Leaking valve stem.

Table 1 shows the mud volume and pressure required in an aging cell for high-temperature aging.

The roller oven was used to heat the mud formulations pressurized in aging cells at a constant temperature. There are two types of drilling muds aging: static and dynamic aging. In this study, some drilling fluid formulations were aged dynamically to mimic the interaction between a drilling fluid and well-bore annulus at $100{ }^{\circ} \mathrm{C}$ and $120^{\circ} \mathrm{C}$. The mud formulations were all aged for $16 \mathrm{~h}$. Figure $3 \mathrm{e}$ shows the roller oven (Akpan et al. 2019).

\section{Drilling fluid formulations}

Twelve unweighted drilling muds were prepared in total for their rheological properties and fluid loss measurements. The drilling muds were prepared by mixing 10.5 grams of bentonite clay and specified quantity of other additives in $350 \mathrm{ml}$ (one lab barrel) of tap water and by stirring the
Table 1 Mud volume and pressure for high-temperature aging (OFI Testing Equipment, 2017)

\begin{tabular}{llllll}
\hline Aging temp. $\left({ }^{\circ} \mathrm{F} /{ }^{\circ} \mathrm{C}\right)$ & $\begin{array}{l}\text { Suggested applied } \\
\text { pressure }(\mathrm{psi} / \mathrm{kPa})\end{array}$ & $\begin{array}{l}\text { Mud volume in } \\
260 \mathrm{ml} \mathrm{cell}(\mathrm{ml})\end{array}$ & $\begin{array}{l}\text { Volume } \\
\text { with Teflon } \\
\text { liner }\end{array}$ & $\begin{array}{l}\text { Mud volume in } \\
500 \mathrm{ml} \text { cell }(\mathrm{ml})\end{array}$ & $\begin{array}{l}\text { Volume with } \\
\text { Teflon liner }\end{array}$ \\
\hline $212 / 100$ & $25 / 172$ & 225 & 130 & 450 & 326 \\
$250 / 121$ & $50 / 345$ & 225 & 130 & 450 & 326 \\
$300 / 149$ & $100 / 690$ & 200 & 116 & 425 & 308 \\
$350 / 176$ & $150 / 1034$ & 200 & 116 & 400 & 289 \\
$400 / 204$ & $250 / 1724$ & - & - & 375 & 271 \\
$450 / 232$ & $300 / 2069$ & - & - & 375 & 253 \\
$500 / 260$ & $375 / 2586$ & - & - & 325 & 235 \\
\hline
\end{tabular}


mixture for $30 \mathrm{~min}$ with the Hamilton beach mixer. The mud formulations were aged at $25{ }^{\circ} \mathrm{C}, 100{ }^{\circ} \mathrm{C}, 120{ }^{\circ} \mathrm{C}$ for $16 \mathrm{~h}$. After sixteen hours, they were stirred for another $30 \mathrm{~min}$ before testing at $25{ }^{\circ} \mathrm{C}$. For rheological measurements at $100{ }^{\circ} \mathrm{C}$ and $120^{\circ} \mathrm{C}$, and to avert the mud formulations from boiling at $100{ }^{\circ} \mathrm{C}$ and above, the aging cells were pressurized and thereafter aged dynamically in a roller oven for $16 \mathrm{~h}$ to mimic the circulation of drilling muds in a well-bore. After $16 \mathrm{~h}$, the mud formulations were cooled and stirred for another $30 \mathrm{~min}$ before measuring their rheological properties at $25^{\circ} \mathrm{C}$. The rheological properties of the drilling muds were measured using Model 1100 viscometer. The first set of tests examined the effects of xanthan gum on water-based bentonite muds prepared without salt. The second set of tests evaluated the performance of xanthan gum and diutan gum in water-based bentonite muds prepared without salt. The third set of tests evaluated the effects of salt on water-based bentonite muds containing only XC. The fourth set of tests was focused on the effects of salt on water-based bentonite muds containing diutan gum and XC. The concentrations of the biopolymers in the mud formulations were adequate to change the viscoelastic behavior of the water-based bentonite muds. Table 2 shows the compositions of the drilling mud formulations.

\section{Results and discussion}

The performance of xanthan gum and diutan gum in waterbased bentonite muds prepared without salt and in waterbased bentonite muds containing salt $(\mathrm{NaCl})$ was investigated through hot rolling and API fluid loss tests. Some mud formulations were aged dynamically to simulate drilling fluid flowing in a well-bore. The rheological parameters were measured based on the Herschel-Bulkley analysis model $\left(\tau_{y}, K\right.$, and $\left.n\right)$. The properties of the drilling mud formulations measured- $n, K, \mathrm{PV}, \mathrm{YP}$, and $10-\mathrm{s}$ and 10-min gel strengths, API fluid loss, apparent viscosity, shear stress, YP/PV ratio, and mud cake thickness-are presented in Tables 3 and 4 . The properties of the water-based bentonite mud containing only XC were compared with those of the water-based bentonite muds containing XC and diutan gum.

\section{Properties of the muds prepared without salt}

\section{Rheological properties of drilling muds}

Figure 4 shows the comparison of the viscosities, $n, K$, and low shear rate viscosities of water-based bentonite muds

Table 2 Compositions of the drilling mud formulations

\begin{tabular}{lllllllllllll}
\hline Additives & Mud 1 & Mud 2 & Mud3 & Mud 4 & Mud 5 & Mud 6 & Mud 7 & Mud 8 & Mud 9 & Mud 10 & Mud 11 & Mud 12 \\
\hline Water (bbl) & 1.0 & 1.0 & 1.0 & 1.0 & 1.0 & 1.0 & 1.0 & 1.0 & 1.0 & 1.0 & 1.0 & 1.0 \\
Bentonite (Ibm/gal) & 0.25 & 0.25 & 0.25 & 0.25 & 0.25 & 0.25 & 0.25 & 0.25 & 0.25 & 0.25 & 0.25 & 0.25 \\
XC (Ibm/gal) & 0.05 & 0.05 & 0.05 & 0.02 & 0.02 & 0.02 & 0.05 & 0.05 & 0.05 & 0.02 & 0.02 & 0.02 \\
NaCl (Ibm/gal) & - & - & - & - & - & - & 0.24 & 0.24 & 0.24 & 0.24 & 0.24 & 0.24 \\
Diutan gum (Ibm/gal) & - & - & - & 0.02 & 0.02 & 0.02 & - & - & - & 0.02 & 0.02 & 0.02 \\
\hline
\end{tabular}

Table 3 Properties of the drilling muds prepared without salt

\begin{tabular}{|c|c|c|c|c|c|c|}
\hline & $\begin{array}{l}\text { Mud } 1 \\
\left(\text { ASH@ } 25{ }^{\circ} \mathrm{C}\right)\end{array}$ & $\begin{array}{l}\text { Mud } 2 \\
\left(\text { AHR@ } 100{ }^{\circ} \mathrm{C}\right)\end{array}$ & $\begin{array}{l}\text { Mud } 3 \\
\left(\text { AHR@ } 120^{\circ} \mathrm{C}\right)\end{array}$ & $\begin{array}{l}\text { Mud } 4 \\
\left(\text { ASH@25 }{ }^{\circ} \mathrm{C}\right)\end{array}$ & $\begin{array}{l}\text { Mud 5 } \\
\left(\text { AHR@ } 100{ }^{\circ} \mathrm{C}\right)\end{array}$ & $\begin{array}{l}\text { Mud } 6 \\
\left(\text { AHR@ } 120^{\circ} \mathrm{C}\right)\end{array}$ \\
\hline \multicolumn{7}{|l|}{ Properties } \\
\hline Shear stress@511 s ${ }^{-1}\left(\mathrm{Ib} / 100 \mathrm{ft}^{2}\right)$ & 35.2 & 25.4 & 20.0 & 54.2 & 44.5 & 43.8 \\
\hline Viscosity @ $511 \mathrm{~s}^{-1}(\mathrm{cP})$ & 33.1 & 23.9 & 18.8 & 50.9 & 41.8 & 41.1 \\
\hline LSRV @ $5.1 \mathrm{~s}^{-1}(\mathrm{cP})$ & 1552.7 & 328.6 & 273.7 & 3202.8 & 1912.7 & 1342.2 \\
\hline 10-s gel $\left(\mathrm{Ib} / 100 \mathrm{ft}^{2}\right)$ & 16.0 & 4.0 & 2.0 & 33.0 & 18.0 & 12.0 \\
\hline $10-\min \left(\mathrm{Ib} / 100 \mathrm{ft}^{2}\right)$ & 20.0 & 5.0 & 3.0 & 39.0 & 20.0 & 16.0 \\
\hline Plastic viscosity (PV) (cP) & 16.5 & 17.6 & 14.5 & 19.0 & 16.6 & 23.1 \\
\hline Yield point $(\mathrm{YP})\left(\mathrm{Ib} / 100 \mathrm{ft}^{2}\right)$ & 17.0 & 5.1 & 3.6 & 35.5 & 24.8 & 16.6 \\
\hline $\mathrm{YP} / \mathrm{PV}\left(\mathrm{s}^{-1}\right)$ & 508.0 & 138.8 & 118.9 & 894.8 & 715.5 & 344.2 \\
\hline $\mathrm{n}$ & 0.2 & 0.4 & 0.4 & 0.1 & 0.2 & 0.2 \\
\hline $\mathrm{K}\left(\mathrm{Ib} \cdot \mathrm{s}^{\mathrm{n}} / 100 \mathrm{ft}^{2}\right)$ & 12.0 & 2.0 & 1.4 & 28.0 & 12.5 & 9.8 \\
\hline API fluid loss (ml) & 5.0 & 5.3 & 7.0 & 4.2 & 4.3 & 4.6 \\
\hline Mud cake (mm) & 1.5 & 1.5 & 1.0 & 1.5 & 1.5 & 1.0 \\
\hline
\end{tabular}


Table 4 Properties of the drilling muds containing salt

\begin{tabular}{llllll}
$\begin{array}{l}\text { Mud 7 } \\
\left(\text { ASH@ } 25{ }^{\circ} \mathrm{C}\right)\end{array}$ & $\begin{array}{l}\text { Mud 8 } \\
\left(\text { AHR @ 100 }{ }^{\circ} \mathrm{C}\right)\end{array}$ & $\begin{array}{l}\text { Mud9 } \\
\left(\text { AHR@ } 120{ }^{\circ} \mathrm{C}\right)\end{array}$ & $\begin{array}{l}\text { Mud10 } \\
\left(\text { AHR@25 }{ }^{\circ} \mathrm{C}\right)\end{array}$ & $\begin{array}{l}\text { Mud 9 } \\
\left(\text { AHR@ 100 }{ }^{\circ} \mathrm{C}\right)\end{array}$ & $\begin{array}{l}\text { Mud 12 } \\
(\text { AHR @ 120 }\end{array}$ \\
\hline
\end{tabular}

Properties

\begin{tabular}{|c|c|c|c|c|c|c|}
\hline Shear stress@511 s ${ }^{-1}\left(\mathrm{Ib} / 100 \mathrm{ft}^{2}\right)$ & 51.7 & 30.8 & 22.2 & 44.9 & 55 & 33.8 \\
\hline Viscosity @ $511 \mathrm{~s}^{-1}(\mathrm{cP})$ & 48.6 & 28.9 & 20.8 & 42.2 & 51.7 & 31.8 \\
\hline LSRV @ $5.1 \mathrm{~s}^{-1}(\mathrm{cP})$ & 2330.2 & 920.6 & 413.4 & 2604.7 & 1743.1 & 554.1 \\
\hline 10-s gel $\left(\mathrm{Ib} / 100 \mathrm{ft}^{2}\right)$ & 24.0 & 9.0 & 4.0 & 27.0 & 17.0 & 5.0 \\
\hline 10-min gel $\left(\mathrm{Ib} / 100 \mathrm{ft}^{2}\right)$ & 29.0 & 11.0 & 4.0 & 33.0 & 21.0 & 5.0 \\
\hline Plastic viscosity (PV) (cp) & 22.5 & 18.0 & 14.9 & 15.9 & 27.2 & 22.8 \\
\hline Yield point (YP) (Ib/100ft $\left.{ }^{2}\right)$ & 26.1 & 11.0 & 4.7 & 28.0 & 23.1 & 7.7 \\
\hline $\mathrm{YP} / \mathrm{PV}\left(\mathrm{s}^{-1}\right)$ & 555.5 & 292.7 & 151.1 & 843.4 & 406.7 & 161.7 \\
\hline $\mathrm{n}$ & 0.2 & 0.2 & 0.4 & 0.1 & 0.2 & 0.4 \\
\hline $\mathrm{K}\left(\mathrm{Ib} \cdot \mathrm{S}^{\mathrm{n}} / 100 \mathrm{ft}^{2}\right)$ & 18.6 & 6.0 & 2.0 & 22.3 & 14.1 & 3.2 \\
\hline API fluid loss (ml) & 4.0 & 6.0 & 7.2 & 4.0 & 4.3 & 4.7 \\
\hline Mud cake (mm) & 1.5 & 1.5 & 1.0 & 1.0 & 1.0 & 1.0 \\
\hline
\end{tabular}

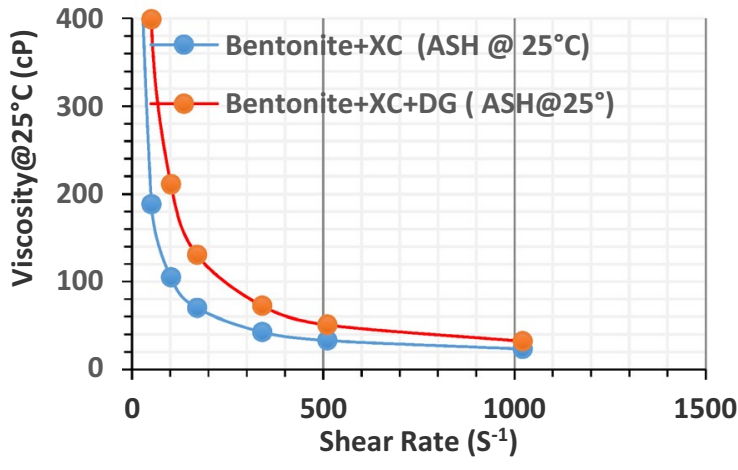

(a)

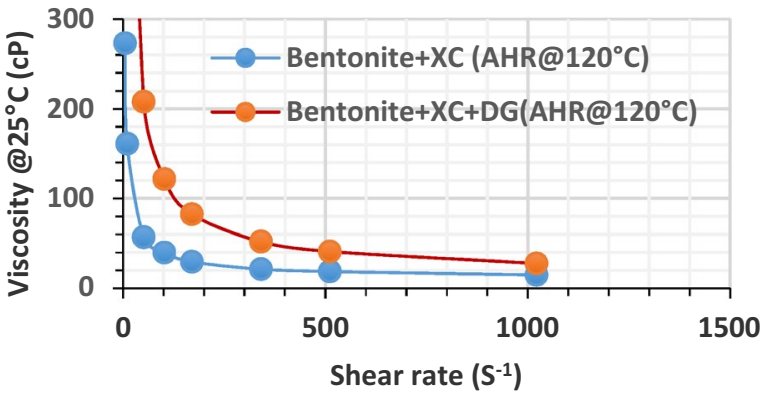

(c)

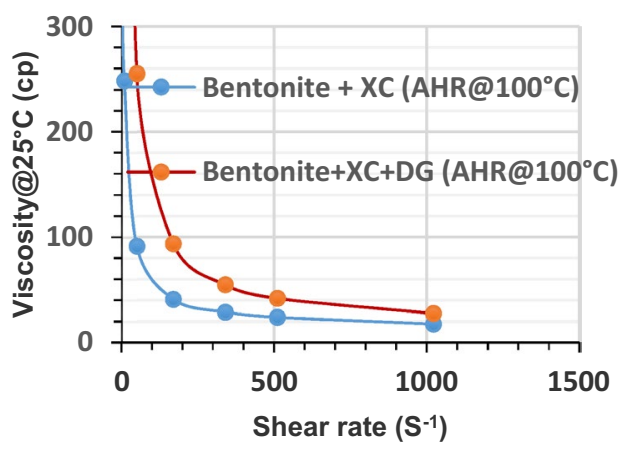

(b)

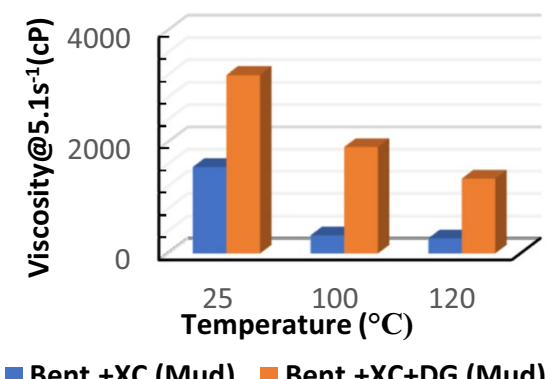

(d)
Fig. 4 Comparison of the properties of mud formulations: a viscosities of mud formulations after static aging at $25{ }^{\circ} \mathrm{C}$ for $16 \mathrm{~h}$; b viscosities of mud formulations after hot rolling at $100{ }^{\circ} \mathrm{C}$ for $16 \mathrm{~h}$; c

containing only XC with those of water-based bentonite muds containing $\mathrm{XC}$ and diutan gum. The viscosities of all the drilling muds decreased as the aging temperatures were viscosities of mud formulations after hot rolling at $120^{\circ} \mathrm{C}$ for $16 \mathrm{~h}$; d low shear rate viscosities of the mud formulations after aging at $25^{\circ} \mathrm{C}, 100{ }^{\circ} \mathrm{C}$, and $120^{\circ} \mathrm{C}$ for $16 \mathrm{~h}$

increased. The decrease in viscosity as the aging temperatures were increased showed that the biopolymers underwent thermal thinning. In addition, the reduction in viscosity of 
drilling muds with increasing temperatures is an indicator of thermal degradation (Howard et al. 2015).

Analysis of Fig. 4 shows that the water-based bentonite muds containing $\mathrm{XC}$ and diutan gum after aging at $25^{\circ} \mathrm{C}$, $100{ }^{\circ} \mathrm{C}$, and $120^{\circ} \mathrm{C}$ for $16 \mathrm{~h}$ had higher viscosities than the water-based bentonite muds containing only XC measured at the same aging temperatures. The high viscosity of the water-based bentonite mud containing XC and diutan gum is an indicator of its thermal stability. The viscosity of the water-based bentonite muds containing only XC decreased drastically after hot rolling at $120^{\circ} \mathrm{C}$ for $16 \mathrm{~h}$. This result shows that at $120^{\circ} \mathrm{C}$ and above for $16 \mathrm{~h}$, xanthan gum in a bentonite mud will lose its functionality because of severe thermal degradation. Consequently, it would be beneficial to use XC and diutan gum together in formations with temperatures up to $120^{\circ} \mathrm{C}$, instead of using only XC in waterbased muds.

The mud formulations exhibited yield-pseudoplastic characteristics as their $\mathrm{n}$ values were less than 1 , and they all had yield points (Mitchel and Miska 2011), and exhibited shear thinning behavior - their viscosities decreased as shear rates increased (Fig. 4a-c). Analysis of Fig. 5 shows that the water-based bentonite muds containing $\mathrm{XC}$ and diutan gum after aging at $25^{\circ} \mathrm{C}, 100{ }^{\circ} \mathrm{C}$, and $120^{\circ} \mathrm{C}$ for $16 \mathrm{~h}$ had lower flow behavior indexes than the water-based bentonite muds containing only XC. In addition, the water-based bentonite mud containing $\mathrm{XC}$ and diutan gum was highly shear thinning as its flow behavior indexes after aging at different temperatures were less than or equal to 0.2. A low value of $\mathrm{n}$ is an indicator of good cuttings transport and hole cleaning potential (Okrajni and Azar 1986). This result shows that the water-based bentonite mud containing XC and diutan gum has better cutting transport and hole cleaning potentials than the bentonite mud containing only XC.

From the power law model equation, $K$ is the viscosity when the shear rate is equal to $1 \mathrm{~s}^{-1}$. As shown in Fig. 6, the $K$ values of the water-based bentonite muds containing $\mathrm{XC}$ and diutan gum after aging at $25^{\circ} \mathrm{C}, 100{ }^{\circ} \mathrm{C}$, and
Fig. 5 Flow behavior index of the mud formulations
Fig. 6 Effects of temperature on the fluid consistency indexes, $K_{\mathrm{s}}$, of the fluid formulations
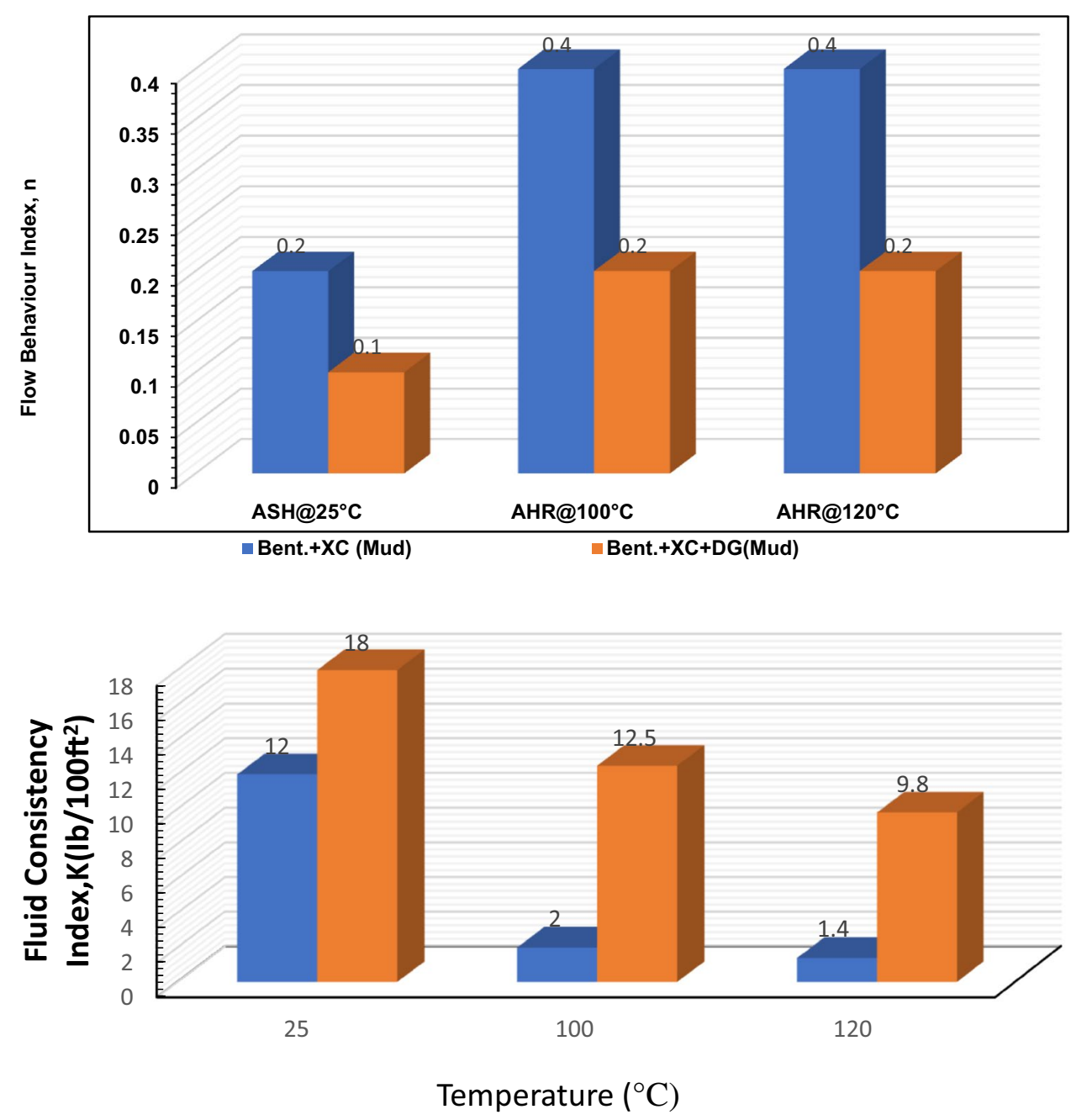

Bent.+XC (Mud) $\quad$ Bent+ XC + Diutan gum (Mud) 
$120{ }^{\circ} \mathrm{C}$ for $16 \mathrm{~h}$ were higher than those of the bentonite muds containing only XC (Fig. 6). Viscosity reduction with increasing temperature indicates drilling mud's degradation (Howard et al. 2015). This result shows that the water-based bentonite mud containing XC and diutan gum is more stable than the water-based bentonite muds containing only XC. In addition, the low shear rate viscosities of the bentonite muds containing XC and diutan gum were higher than those of the water-based bentonite muds containing only XC (Fig. 4d). A high low shear rate viscosity is vital for solid suspension (Sarber et al. 2010; Seeberger et al. 1989; Powell et al. 1991; Zamora et al. 1993). The high low shear rate viscosity of the bentonite mud containing XC and diutan gum indicates good suspension characteristics. It is evident that diutan gum protected XC from thermal degradation or acted as a sacrificial agent. This comparative study, therefore, clearly demonstrates that diutan gum is effective in stabilizing xanthan gum in a water-based bentonite mud.

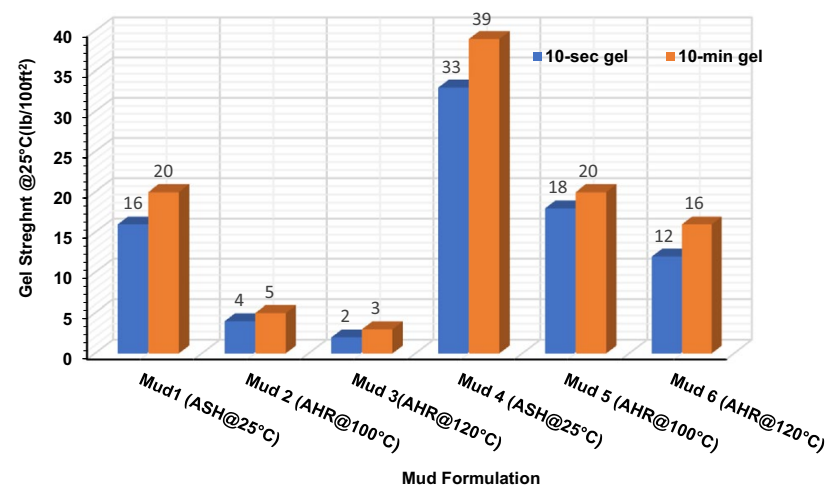

Fig. 7 Comparison of the gel strength of the drilling muds

\section{Gel strengths of the drilling muds}

Figure 7 compares the gelling characteristics of bentonite muds containing only $\mathrm{XC}$ with those of bentonite muds containing $\mathrm{XC}$ and diutan gum. The gel strengths indicate the thixotropic characteristics of drilling fluids. Therefore, all the mud formulation exhibited thixotropic characteristics. The 10-s and 10-min gel strengths of all the drilling muds decreased as the aging temperatures were increased. Gel strength is increased by flocculation, deflocculation decreases gel strength in water-based muds (Annis and Smith 1996). The reduction in the gel strengths can, therefore, be attributed to the deflocculation of the drilling muds as the aging temperatures were increased. However, the bentonite muds containing XC and diutan had higher gel strengths than the bentonite muds containing only $\mathrm{XC}$ after hot rolling at $100{ }^{\circ} \mathrm{C}$ and $120^{\circ} \mathrm{C}$ for $16 \mathrm{~h}$ (Fig. 7). The high gel strength characteristic is due to the XC-diutan gum mud containing more electrically charged particles that link together to create a firm structure in the mud. This result shows that the water-based bentonite muds containing XC and diutan gum have good gelling potentials to suspend solids when circulation is stopped. In addition, the bentonite mud containing XC and diutan will also be more suitable for horizontal well drilling as it has a higher 10-s gel than the bentonite muds containing only $\mathrm{XC}$.

\section{API fluid loss and mud cake thickness of the drilling muds}

Figure 8 shows the effects of XC and diutan gum on the API fluid loss of bentonite muds measured at room temperature and a pressure of $100 \mathrm{psi}$ for $30 \mathrm{~min}$. All the mud formulations have favorable filter cake building properties as shown by their thin mud cakes (Table 3). Comparison of the API fluid losses of the muds containing only XC and with those of the muds containing $\mathrm{XC}$ and diutan gum showed that
Fig. 8 API fluid losses of the mud formulations after aging at $25^{\circ} \mathrm{C}, 100{ }^{\circ} \mathrm{C}$, and $120^{\circ} \mathrm{C}$

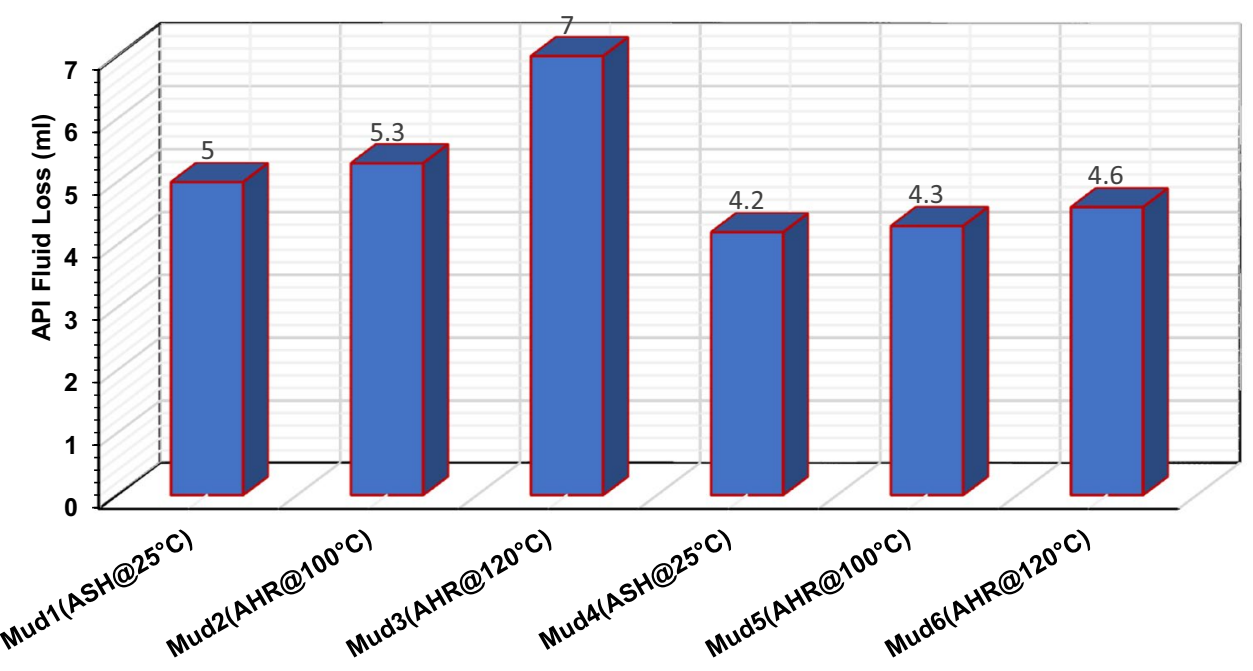


XC-diutan gum muds have better fluid loss control potentials than the water-based bentonite muds containing only $\mathrm{XC}$ after aging at $25^{\circ} \mathrm{C}, 100{ }^{\circ} \mathrm{C}$, and $120^{\circ} \mathrm{C}$ for $16 \mathrm{~h}$. The bentonite muds containing only $\mathrm{XC}$ show significant thermal degradation at $120^{\circ} \mathrm{C}$ as reflected by its high API fluid loss. This result shows that the bentonite mud containing XC and diutan gum is more stable than the bentonite muds containing only XC. The experimental data show a $16 \% 19 \%$, $34 \%$ reduction in API fluid loss for the water-benitoite muds containing $\mathrm{XC}$ in the presence of diutan gum after aging at $25{ }^{\circ} \mathrm{C}, 100{ }^{\circ} \mathrm{C}$, and $120^{\circ} \mathrm{C}$ for $16 \mathrm{~h}$, respectively. For this reason, the bentonite mud containing $\mathrm{XC}$ and diutan gum has good API fluid loss control characteristics. The reason for the low API fluid loss of the bentonite mud containing $\mathrm{XC}$ and diutan gum could be due to the swelling and tolerance of diutan gum to increasing temperatures, thereby depositing a thin, low-permeability mud cake on the filter paper. From Eq. (6), the variables that contributed to the low API fluid loss of the bentonite mud containing XC and diutan gum are its high filtrate viscosity and the low permeability of its thin mud cake. The bentonite mud containing $\mathrm{XC}$ and diutan gum will cause less formation damage since its thin, low-permeability mud cake will prevent fines from invading a formation. Combining xanthan and diutan in a ratio of 1:1, therefore, improves the fluid loss characteristics of water-based bentonite mud better than using only XC.

\section{The YP/PV ratios of the drilling muds}

Figure 9 compares the YP/PV ratio results of bentonite muds containing only XC with those of the bentonite muds containing XC and diutan gum. The bentonite muds containing $\mathrm{XC}$ and diutan gum have higher YP/PV ratios than bentonite mud containing only $\mathrm{XC}$ after aging at different temperatures for $16 \mathrm{~h}$. The bentonite muds containing XC and diutan gum also have $\mathrm{n}$ values that are less than or equal to 0.3. A high (YP/PV) ratio or low $n$ value provides better cuttings transport and hole cleaning (Okrajni and Azar 1986). These results show that the bentonite muds containing XC and diutan gum will transport cuttings to the surface better than the bentonite muds containing only XC.

\section{The yield points of the drilling muds}

Figure 10 compares the yield points of bentonite muds containing only XC with those of the bentonite muds containing $\mathrm{XC}$ and diutan gum. The yield points of all the mud formulations decreased as the aging temperatures were increased. Experimental data show that the bentonite muds containing $\mathrm{XC}$ and diutan gum have yield points that are higher than bentonite muds containing only $\mathrm{XC}$ after aging at $25{ }^{\circ} \mathrm{C}$, $100{ }^{\circ} \mathrm{C}$, and $120^{\circ} \mathrm{C}$ for $16 \mathrm{~h}$. A high yield point enhances the solids carrying characteristics of drilling fluid and increases the pressure drop in the well-bore (Annis and Smith 1996). The bentonite muds containing XC and diutan gum will, therefore, carry cuttings better than the bentonite mud containing only XC.

\section{Effects of salt on the drilling muds}

Figure 11 compares the effects of salts $(\mathrm{NaCl})$ on the apparent viscosities of water-based bentonite muds containing XC and diutan gum and water-based bentonite muds containing only XC. The water-based bentonite mud containing only $\mathrm{XC}$ had a higher viscosity after aging at a low temperature of $25^{\circ} \mathrm{C}$ (Fig. 11a); but as the aging temperatures were increased, the viscosities of bentonite muds containing XC and diutan gum were higher (Fig. 11b, c). The experimental data show that bentonite muds containing $\mathrm{XC}$ and diutan gum were tolerant of contamination with salt $(\mathrm{NaCl})$ as their apparent viscosities were higher than those of the waterbased bentonite muds containing only $\mathrm{XC}$ after hot rolling at $100{ }^{\circ} \mathrm{C}$ and $120^{\circ} \mathrm{C}$ for $16 \mathrm{~h}$. This result also shows that in presence of salt, the water-based bentonite mud containing $\mathrm{XC}$ and diutan gum was more stable than the waterbased bentonite muds containing only XC. It would be
Fig. 9 YP/PV ratios of the mud formulations

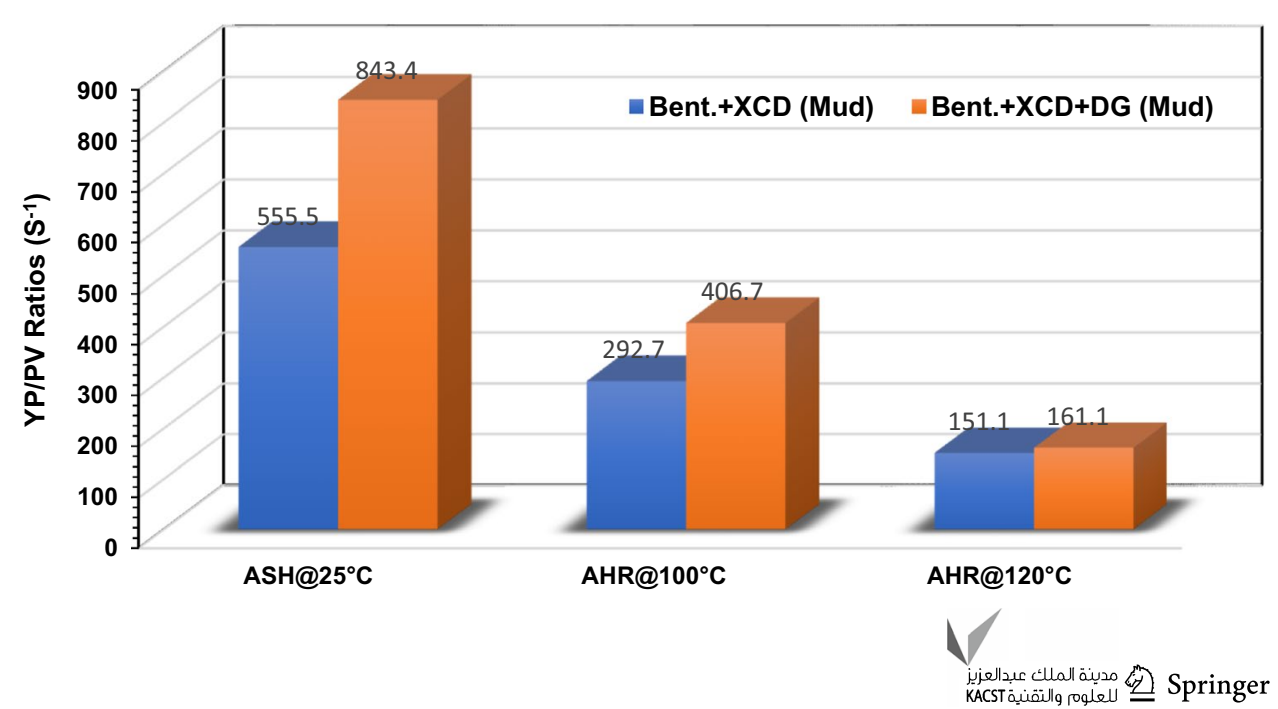


Fig. 10 Yield points of the drilling muds

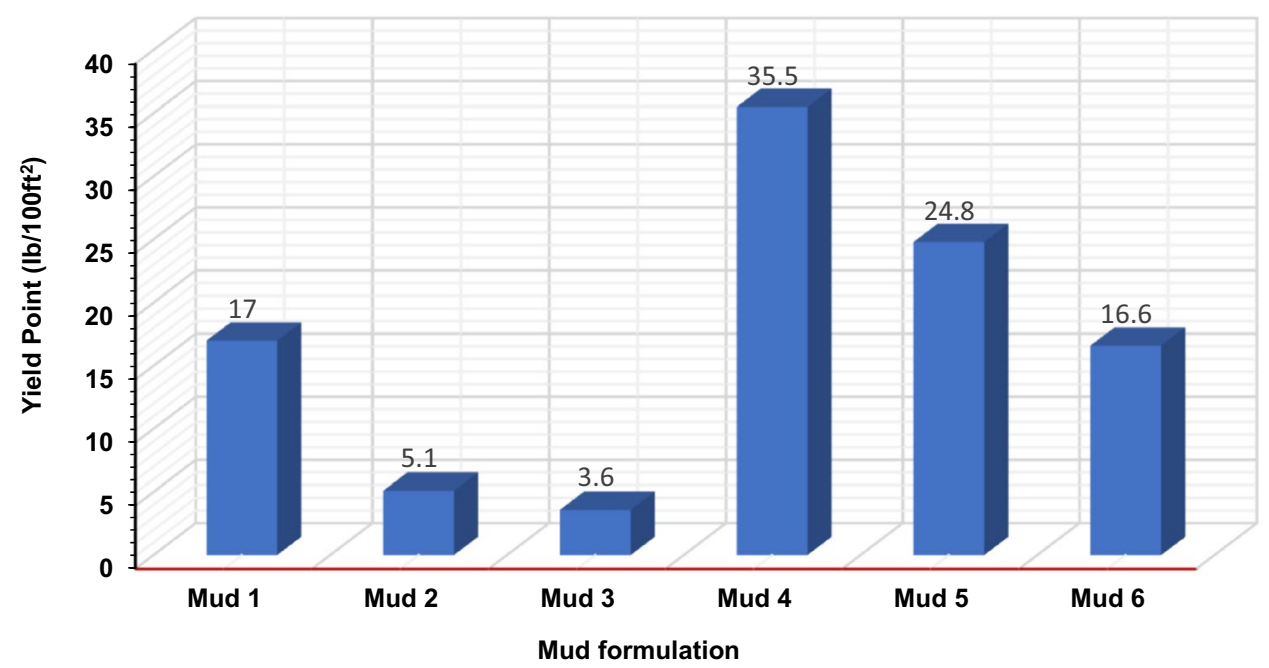

advantageous to use water-based bentonite muds containing $\mathrm{XC}$ and diutan gum where thermal stability and resistant to salt contamination are required instead of using water-based bentonite muds containing only XC.

Figure 12 compares the effects of salt on the gelling characteristics of water-based bentonite muds containing only $\mathrm{XC}$ and both XC and diutan gum. All the mud formulations show a reduction in gel strengths after aging at $100{ }^{\circ} \mathrm{C}$ and $120^{\circ} \mathrm{C}$. However, the water-based bentonite muds containing $\mathrm{XC}$ and diutan gum have higher gel strengths than the water-based bentonite muds containing only $\mathrm{XC}$ after aging at $25{ }^{\circ} \mathrm{C}, 100{ }^{\circ} \mathrm{C}, 120{ }^{\circ} \mathrm{C}$ for $16 \mathrm{~h}$. The water-based bentonite muds containing $\mathrm{XC}$ and diutan gum, therefore, have good gelling potentials to suspend solids when circulation is stopped.

Figure 13 shows the effects of salt on the YP/PV ratios of water-based bentonite muds containing only $\mathrm{XC}$ and both $\mathrm{XC}$ and diutan gum after aging at $25^{\circ} \mathrm{C}, 100^{\circ} \mathrm{C}$, and $120^{\circ} \mathrm{C}$ for $16 \mathrm{~h}$. The YP/PV ratios of all the drilling muds decreased as the aging temperatures were increased. However, the water-based bentonite mud containing $\mathrm{XC}$ and diutan gum has higher YP/PV ratios than water-based bentonite muds containing only $\mathrm{XC}$. In addition, the water-based bentonite muds containing $\mathrm{XC}$ and diutan gum have $\mathrm{n}$ values that are less than 0.5 (Table 4), thus showing that the fluid formulation is highly shear thinning. These results show that the water-based bentonite muds containing XC and diutan gum will transport cuttings to the surface better than the waterbased bentonite muds containing only XC.

Figure 14 shows the comparison of the properties of drilling muds containing a salt after aging at different temperatures. Figure 14a compares the low shear rate viscosities of the water-based bentonite muds containing only XC gum with those of the water-based bentonite muds containing $\mathrm{XC}$ and diutan gum. The low shear rate viscosities of the bentonite muds containing XC and diutan gum were higher than those of the water-based bentonite muds containing only XC. These high low shear rate viscosities indicate that in the presence of salt, the bentonite muds containing XC and diutan gum will suspend drilled cuttings and weighting material better than the water-based bentonite muds containing only XC during drilling.

Figure $14 \mathrm{~b}$ compares the effects of salt on the API fluid loss of water-based bentonite muds containing only XC and both $\mathrm{XC}$ and diutan gum measured at room temperature and a pressure of $100 \mathrm{psi}$ for $30 \mathrm{~min}$. The API fluid losses of the water-based bentonite muds containing $\mathrm{XC}$ and diutan gum were less than those of the water-based bentonite muds containing only $\mathrm{XC}$ after aging at $100^{\circ} \mathrm{C}$ and $120^{\circ} \mathrm{C}$. This result shows that the water-based bentonite muds containing $\mathrm{XC}$ and diutan gum were tolerant toward increasing temperature than the water-based bentonite muds containing only XC. This result also shows that the water-based bentonite muds containing XC and diutan gum will lose less fluid to the formation in the presence of salt $(\mathrm{NaCl})$ than water-based bentonite muds containing only XC. The bentonite mud containing $\mathrm{XC}$ and diutan gum will cause less formation damage since its thin, low-permeability mud cake will prevent fines from penetrating a formation.

Figure $14 \mathrm{c}$ compares the yield points of the water-based bentonite muds containing XC gum with those of the waterbased bentonite muds containing XC and diutan gum. All the mud formulations show a decrease in yield points after hot rolling at $100{ }^{\circ} \mathrm{C}$ and $120^{\circ} \mathrm{C}$ for $16 \mathrm{~h}$. Despite the reduction in yield points, water-based bentonite muds containing $\mathrm{XC}$ and diutan gum had higher yield points than water-based bentonite muds containing only XC. A high yield point implies that a drilling mud is non-Newtonian and can carry cutting better than a drilling mud with a lower yield point. The high yield points of the water-based bentonite mud containing XC and diutan gum, therefore, indicate good cuttings and weighting material carrying potentials. 


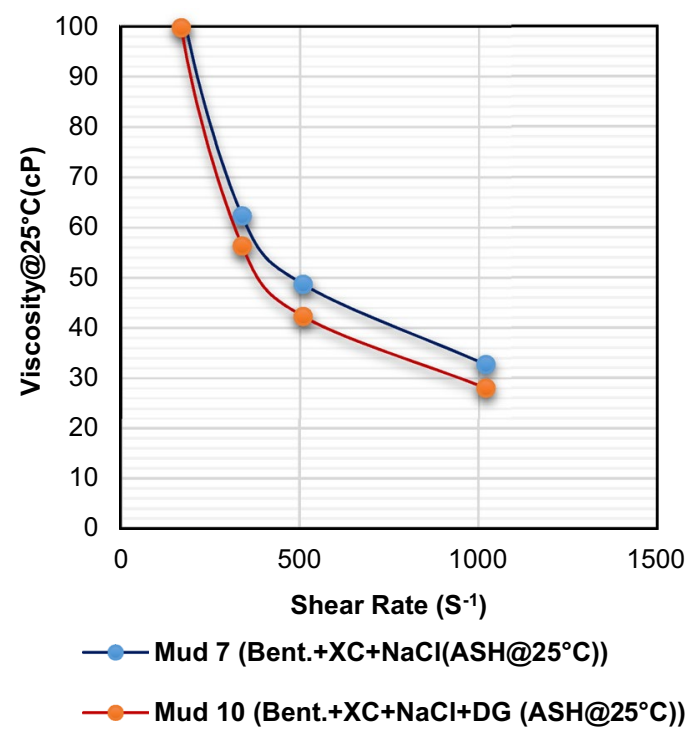

(a)
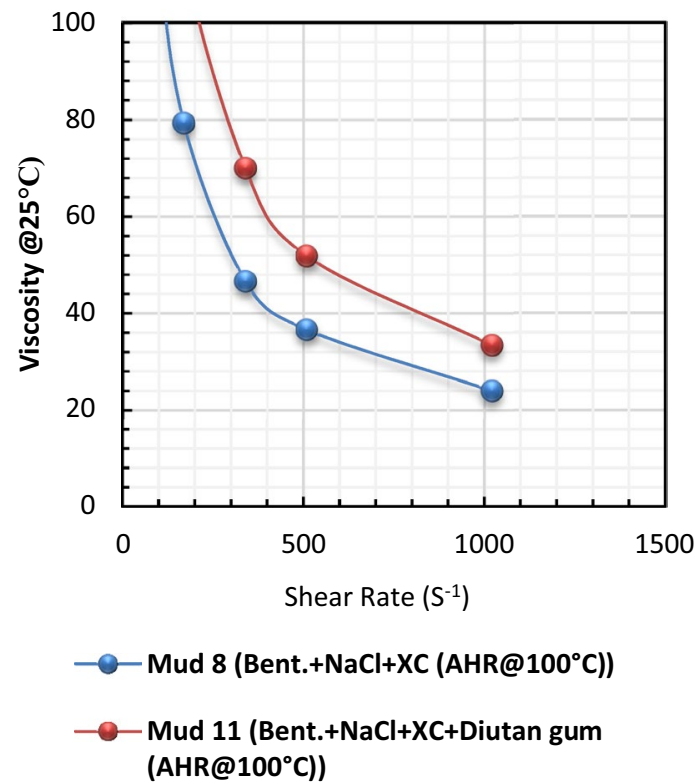

(b)

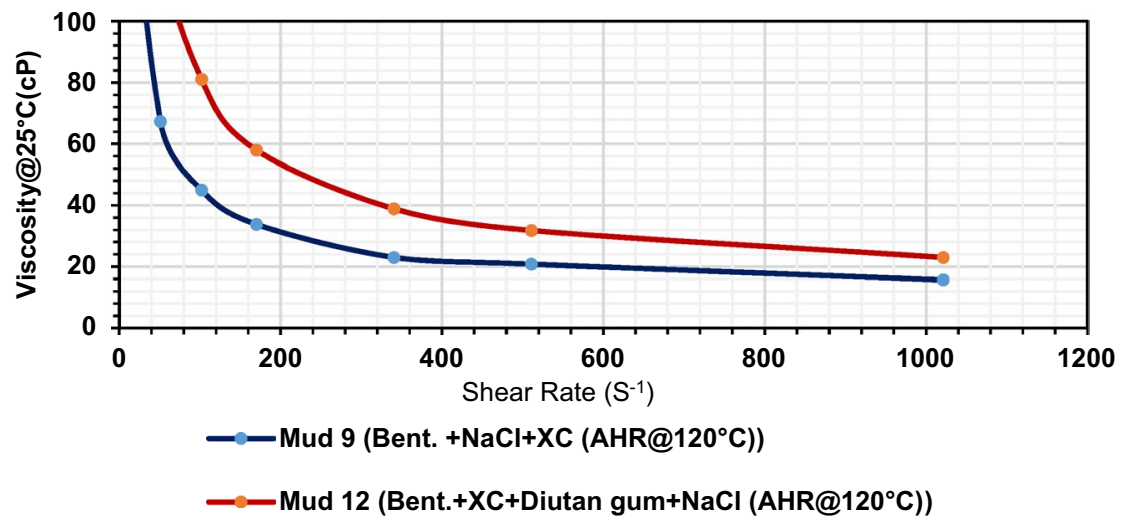

(c)

Fig. 11 Comparison of the viscosities of drilling muds containing a salt: a viscosities of mud formulations after static aging at $25^{\circ} \mathrm{C}$; $\mathbf{b}$ viscosities of mud formulations after hot rolling at $100^{\circ} \mathrm{C}$; c viscosities of mud formulations after hot rolling at $120^{\circ} \mathrm{C}$

Fig. 12 Gel strengths of the drilling muds

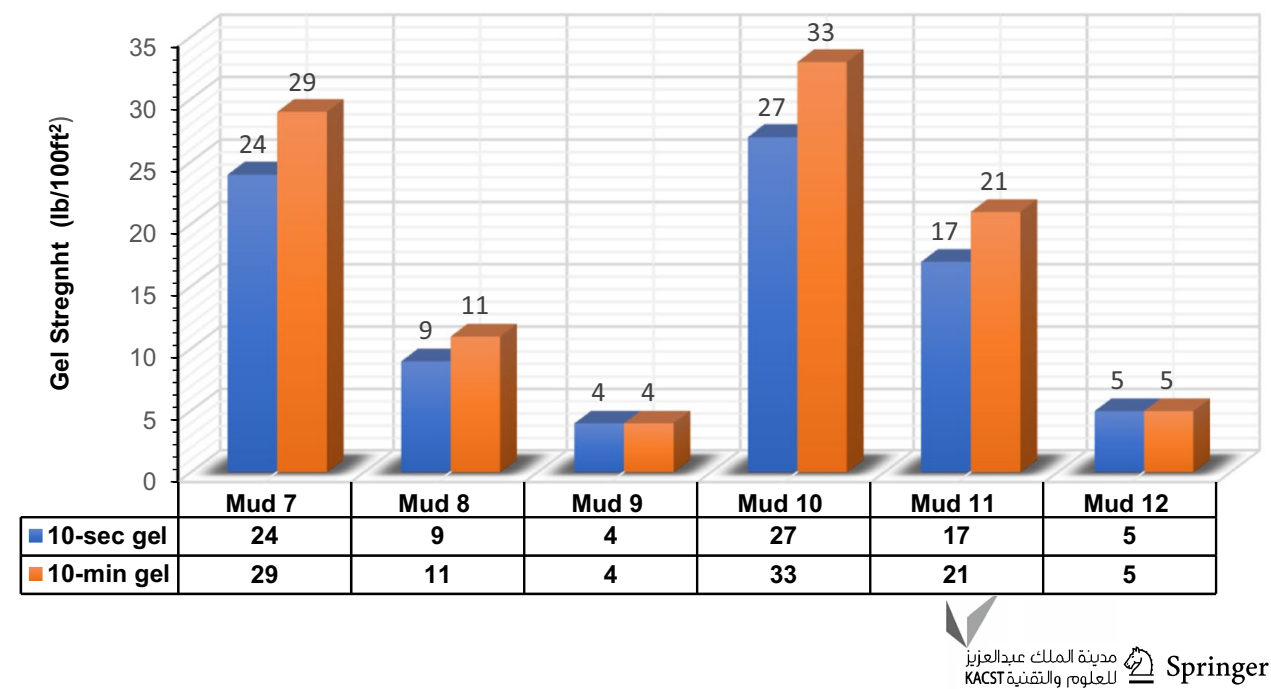




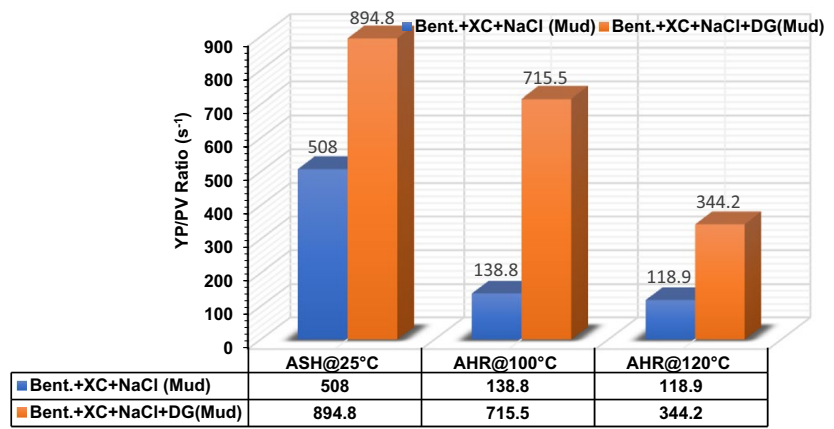

Fig. 13 Comparison of the YP/PV ratios of the drilling muds containing a salt

\section{Conclusion}

The objective of this study was to investigate the effects of an eco-friendly biopolymer (diutan gum) on a widely used industry polymer (xanthan gum) in a water-based bentonite muds prepared without salt and in a water-based bentonite mud containing salt $(\mathrm{NaCl})$. Laboratory experiments were carried out for different compositions of the biopolymers in water-based bentonite muds to ascertain the optimum of fluid performance; the properties of waterbased bentonite muds containing only $\mathrm{XC}$ were compared with those of water-based bentonite muds containing XC and diutan gum as soluble polymers. The following conclusions were made:

1. Combining diutan gum and xanthan gum in a ratio of 1:1 enhances the performances of water-based bentonite mud.

2. The bentonite mud containing $\mathrm{XC}$ and diutan gum will cause less formation damage since its thin, low-permeability mud cake will prevent fines from invading a formation.

3. Experimental data indicate a $16 \%, 19 \%$, and $34 \%$ reduction in API fluid loss values for the water-based benitoite muds containing only $\mathrm{XC}$ in the presence of diutan gum after aging at $25^{\circ} \mathrm{C}, 100^{\circ} \mathrm{C}$, and $120^{\circ} \mathrm{C}$ for $16 \mathrm{~h}$, respectively.

4. Diutan gum improves the resistance of water-based bentonite muds containing xanthan gum to salt contamination.

5. Diutan gum improved the static filtration loss characteristics of water-based bentonite muds containing xanthan gum, even in the presence of salt.
Fig. 14 Comparison of the properties of drilling muds containing a salt after aging at $25^{\circ} \mathrm{C}, 100{ }^{\circ} \mathrm{C}$, and $120^{\circ} \mathrm{C}$ : a low shear rate viscosities of the drilling muds; $\mathbf{b}$ API fluid losses of the drilling muds; $\mathbf{c}$ yield points of the drilling muds

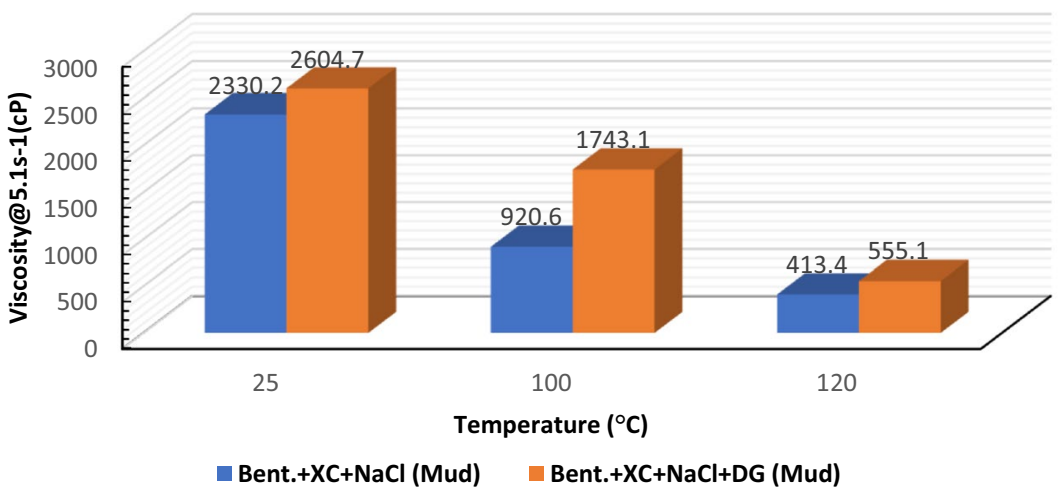

(a)

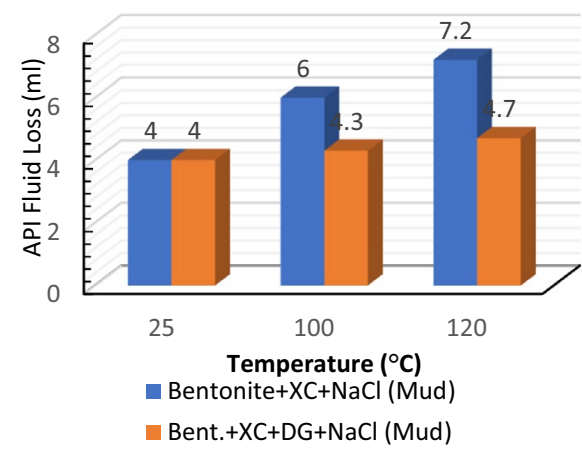

(b)

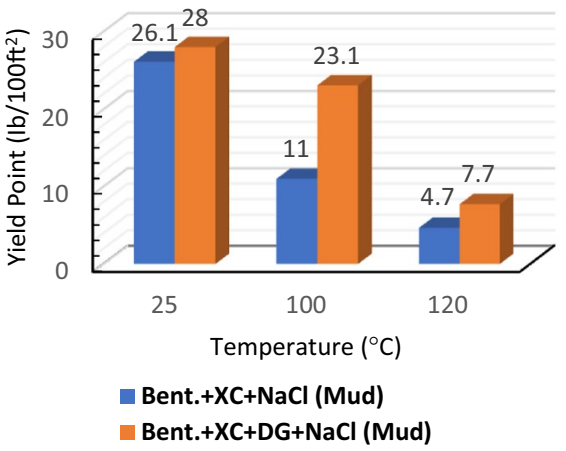

(c) 
6. Diutan gum enhances the suspension potentials, hole cleaning characteristics, and drilled cuttings and weighting material carrying capacity of water-based bentonite muds containing xanthan gum.

7. Diutan gum protected XC from thermal degradation or acted as a sacrificial agent.

8. Diutan gum improved the gelling characteristics of water-based bentonite muds containing xanthan gum.

9. The synergy of diutan gum and xanthan gum enhanced the thermal stability of xanthan gum and improved the performance of water-based bentonite mud.

Open Access This article is licensed under a Creative Commons Attribution 4.0 International License, which permits use, sharing, adaptation, distribution and reproduction in any medium or format, as long as you give appropriate credit to the original author(s) and the source, provide a link to the Creative Commons licence, and indicate if changes were made. The images or other third party material in this article are included in the article's Creative Commons licence, unless indicated otherwise in a credit line to the material. If material is not included in the article's Creative Commons licence and your intended use is not permitted by statutory regulation or exceeds the permitted use, you will need to obtain permission directly from the copyright holder. To view a copy of this licence, visit http://creativecommons.org/licenses/by/4.0/.

\section{References}

Abdon CJ, Jackson LB, McClelland SG (1989) The development of a deflocculated polymer mud for HTHP drilling. Paper presented at the SPE Middle East Oil Show, Bahrain. https://doi. org/10.2118/17924-ms

Adebayo AR, Bageri BS (2019) A simple NMR methodology for evaluating filter cake properties and drilling fluid-induced formation damage. J Pet Explor Prod Technol. https://doi. org/10.1007/s13202-019-00786-3

Akpan EU et al (2019) Water-based drilling fluids for high-temperature applications and water-sensitive and dispersible shale formations. JPSE 175:1028-1038. https://doi.org/10.1016/j. petrol.2019.01.002

Al-Azani K et al (2019) Cutting concentration prediction in horizontal and deviated wells using artificial intelligence techniques. J Pet Explor Prod Technol 9(04):2769-2779. https:// doi.org/10.1007/s13202-019-0672-3

Amoco Production Company (1994) Drilling fluids manual. https ://oilfieldteam.com/static/uploads/uploaded_files/973f0f7560 355125ebc95627ffe73527.pdf. Accessed 20 Jan 2019

Annis RM, Smith VM (1996) Drilling fluids technology. EXXON Company, Irving

Bradshaw JR, Hodge MR, Wolf ON, Knox AD, Hudson EC, Evans E (2006) Formate-based reservoir drilling fluid resolves hightemperature challenges in the Natuna Sea. Paper presented at the SPE international symposium and exhibition on formation damage control, Lafayette, Louisiana, USA. https://doi. org/10.2118/98347-ms

Cano-Barrita JFP, Leon-Matinez MF (2016) Biopolymers with viscosity-enhancing properties for concrete. https://www.scien cedirect.com/science/article/pii/B9780081002148000117. Accessed 14 Mar 2018

Chilingarian GV, Vorabutr P (1981) Drilling and drilling fluids. Elsevier, Amsterdam
Darley HCH, Gray GR (1988) Composition and properties of drilling fluids. Gulf Publishing, Houston

Dayawant S (1999) An innovative, environmentally friendly and cost-effective approach for polymer-based mud system in Upper Assam oil fields of India. Paper presented at the SPE/IADC middle east drilling technology conference, Abu Dhabi, UAE. https://doi.org/10.2118/57584-ms

Demirdal B et al (2007) Drilling fluids rheological and volumetric characterization under downhole conditions. Paper presented at the SPE Latin American \& Caribbean petroleum engineering conference, Buenos Aires, Argentina. https://doi. org/10.2118/108111-ms

Ezell R, Ezzat D, Turnerm KJ, Wu JJ (2010) New filtration-control polymer for improved brine-based reservoir drilling-fluids performance at temperatures in excess of 400 of and high pressure. Paper presented at the SPE international symposium and exhibition on formation damage control, Lafayette, Louisiana, USA. https://doi.org/10.2118/128119-ms

Galindo AK et al (2015) High temperature, high-performance waterbased drilling fluid for extreme high-temperature wells. Paper presented at The SPE international symposium on oilfield chemistry, The Woodlands, Texas, USA. https://doi.org/10.2118/173773-ms

Gallino GP, Xiao L (1996) Scleroglucan biopolymer enhances WBM performances. Paper presented at the SPE annual technical conference and exhibition Denver, Colorado. https://doi. org/10.2118/36426-ms

Gallino G, Guarneri A, Maglione R, Nunzi P, Xiao LP (1997) New formulations of potassium acetate and potassium formate polymer muds greatly improved drilling and waste disposal operations in South Italy. Paper presented at the SPE production operations symposium, Oklahoma City, Oklahoma. https://doi. org/10.2118/37471-ms

Hemphill T, Campos W, Pilehvari A (1993) Yield-power law model more accurately predicts mud rheology. Oil Gas J 91(34):45-50

Howard KS (1995) Formate brines for drilling and completion: stateof-the art. Paper presented at the SPE annual technical conference and exhibition, Dallas, Texas. https://doi.org/10.2118/30498-ms

Howard S, Kaminski L, Downs J (2015) Xanthan stability in formate brine-formulating non-damaging fluids for high-temperature applications. Paper presented at rthe SPE European formation damage conference and exhibition held in Budapest, Hungary. https://doi.org/10.2118/174228-ms

Kjøsnes GL, Saasen A, Syrstad OS, Agle A, Solvang KA (2003) Successful water-based drilling fluid design for optimising hole cleaning and hole stability. Paper presented at the SPE/IADC middle east drilling technology conference and exhibition, Abu Dhabi, United Arab Emirates. https://doi.org/10.2118/85330-ms

Kumara SM, Khan BA, Rohit KC, Purushotham B (2012) Effect of carbon and nitrogen sources on the production of xanthan gum from Xanthomonas campestris isolated from soil. Arch Appl Sci Res 4(6):2507-2512

Mahto V et al (2004) Rheological study of water-based oil well drilling fluid. JPSE 45(1-2):123-128. https://doi.org/10.1016/j.petro 1.2004.03.008

Mahto V et al (2005) Tragacanth gum: an effective oil well drilling fluid additive. Energy Sources 27(3):299-308. https://doi. org/10.1080/00908310390424142

Melo et al (1995) An innovative model for drilling fluid hydraulic. Paper presented at the SPE Asia Pacific oil and gas conference, Kuala Lumpur. https://doi.org/10.2118/99162-MS

Mitchel RF, Miska SZ (2011) Fundamentals of drilling engineering. Society of Petroleum Engineers, Richardson

Navarrete CR, Seheult MJ, Coffey DM (2001) New biopolymers for drilling, drill-In, completions, spacer, and coil-tubing fluids, part II. Paper presented at the SPE international symposium on oilfield chemistry, Houston, Texas. https://doi.org/10.2118/64982-ms

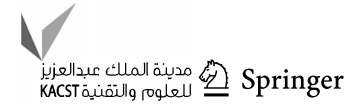


OFI Testing Equipment, Inc. (2015) Modell 1100 pressurised viscometer (instruction manual). http://www.ofite.com/publications/instr uctions/128-130-81-instructions/file. Accessed 16 Feb 2019

OFI Testing Equipment, Inc. (2017) Aging cell instruction manual. http://www.ofite.com/doc/175-25_instructions.pdf. Accessed 16 Feb 2019

Okrajni S, Azar JJ (1986) The effects of mud rheology on annular hole cleaning in directional wells. SPE Drill Eng 1(04):297-308. https ://doi.org/10.2118/14178-PA

Plank JP (1992) Water based muds using synthetic polymers developed for high temperature drilling. Oil Gas J 90(5):40-45

Powel WJ, Stephens PM, Seheult MJ, Sifferman T, Swazey J (1995) Minimisation of formation damage, filter cake deposition, \& stuck pipe potential in horizontal wells through the use of time-independent viscoelastic yield stress fluids \& filtrates. Paper presented at the SPE/ADC drilling conference, Amsterdam, Netherlands. https://doi.org/10.2118/29408-ms

Powell JW, Parks CF, Seheult JM (1991) Xanthan and welan: the effects of critical polymer concentration on rheology and fluid performance. Paper presented at the SPE international arctic technology conference, Anchorage, Alaska. https://doi.org/10.2118/22066-ms

Sakata N, Yanai S, Yokosaki K, Maruyama K (2003) Study on new viscosity agent for combination use type of self-compacting concrete. J Adv Concr Technol I(1):37-41. https://doi.org/10.3151/jact.1.37

Samaei MS, Tahmasbi K (2007) The possibility of replacing oil-based mud with the environmentally acceptable water-based glycol drilling mud for the Iranian fields. Paper presented at the SPE \&P environmental and safety conference, Galveston, Texas, U.S.A. https://doi.org/10.2118/106419-ms

Sancet et al (2018) Molecular structure characterization and interaction of a polymer blend of xanthan gum-polyacrylamide to improve mobility-control on a mature polymer flood. Paper presented at the SPE EOR conference at oil and gas West Asia. https://doi. org/10.2118/190408-MS

Sarber GJ, Reynolds C, Michel MC, Haag K, Morris AR (2010) The use of diutan biopolymer in coiled tubing drilling mud systems on the north slope of Alaska. Paper presented at the SPE/ICOTA coiled tubing and well intervention conference and exhibition, The Woodlands, Texas, USA, 23-24 March 2010. https://doi. org/10.2118/130584-MS

Seeberger MH, Matlock RW, Hanson PM (1989) Oil muds in largediameter, highly deviated wells: solving the cuttings removal problem. Paper presented at the SPE/IADC drilling conference, New Orleans, Louisiana. https://doi.org/10.2118/18635-ms

Sharma VP, Mahto V (2006) Studies on less expensive environmentally safe polymers for development of water-based drilling fluids. Paper presented at the SPE Asia Pacific oil \& gas conference and exhibition, Adelaide, Australia. https://doi.org/10.2118/10090 3-ms

Sharma VP et al (2003) Behaviour of organic polymers on the rheological properties of Indian bentonite-water based drilling fluid system and its effect on formation damage. Indian J Chem Technol 10:525-530

Strickland DS (1994) Polymer drilling fluids in the 1990's: will they replace oil-based muds? J Pet Technol 46(08):619-714. https:// doi.org/10.2118/29211-PA

Sutherland WI (1996) Extracellular polysaccharides. In: Rehm HJ, Reed G (eds) Biotechnology. VCH, New York, pp 613-657

Tehrani MA et al (2007) A water-based drilling fluid for HT/HP applications. Paper presented at the 2007 SPE international symposium on oil field chemistry, Houston, Texas, USA. https://doi. org/10.2118/105485-ms

Tehrani A, Young S, Gerrard D, Fernandez J (2009) Environmentally friendly water-based fluid for HT/HP drilling. Paper presented at the SPE international symposium on oilfield chemistry, The Woodlands, Texas. https://doi.org/10.2118/121783-ms

Ujma KHW, Preussag GA, Plank PJ (1989) A new calcium-tolerant polymer helps to improve drilling-mud performance and reduce costs. Paper presented at the SPE annual technical conference and exhibition, Dallas, Texas. https://doi.org/10.2118/16685-ms

Weaver J et al (2003) Guar gum degradation: a kinetic study. Paper presented at the SPE international symposium on oilfield chemistry, Houston, Texas. https://doi.org/10.2118/80226-ms

Wenjun S et al (2014) Research on the drilling fluid technology for high temperature over $240{ }^{\circ} \mathrm{C}$. Procedia Eng 73:218-229. https://doi. org/10.1016/j.proeng.2014.06.191

Young S, Ramses G (2006) Drilling performance and environmental compliance-resolution of both with a unique water-based fluid. Paper presented at the SPE/IADC Indian drilling technology conference and exhibition, Mumbai, India, 16-18 Oct. https://doi. org/10.2118/103967-ms

Zamora M, Jefferson DT, Powell JW (1993) Hole-cleaning study of polymer-based drilling fluids. Paper presented at the SPE annual technical conference and exhibition, Houston, Texas. https://doi. org/10.2118/26329-ms

Zhang MX (2016) The development of a viscosifier for clay free and water-based drilling fluid with high density and high temperature resistant. Paper presented at the IADC/SPE Asia Pacific conference, Singapore, 22-24 Aug. https://doi.org/10.2118/180662-ms

Zheng W, Wu X, Huang Y (2019) Impact of polymer addition, electrolyte, clay and antioxidant on rheological properties of polymer fluid at high temperature and high pressure. J Pet Explor Prod Technol. https://doi.org/10.1007/s13202-019-0732-8

Publisher's Note Springer Nature remains neutral with regard to jurisdictional claims in published maps and institutional affiliations. 